\title{
Determination of key-thermodynamic parameters using a kinetic modeling approach to describe the post-consumer poly(ethylene terephthalate) hydrolysis catalyzed by cutinase from Humicola insolens
}

Erika de Queiros Eugenio ( $\nabla$ erikaqe@fat.uerj.br)

Universidade do Estado do Rio de Janeiro https://orcid.org/0000-0003-3927-0414

Ivone Sampaio Pereira Campisano

Universidade Federal do Rio de Janeiro

Aline Machado de Castro

Petrobras

\section{Maria Alice Zarur Coelho}

Universidade Federal do Rio de Janeiro Escola de Química: Universidade Federal do Rio de Janeiro

Escola de Quimica

Marta Antunes Pereira Langone

UERJ: Universidade do Estado do Rio de Janeiro https://orcid.org/0000-0002-5489-9571

\section{Research Article}

Keywords: PET biodegradation, Humicola insolens cutinase, Kinetic parameters, Heterogeneous biocatalysis

Posted Date: February 17th, 2021

DOl: https://doi.org/10.21203/rs.3.rs-204586/v1

License: (1) (1) This work is licensed under a Creative Commons Attribution 4.0 International License.

Read Full License 
Determination of key-thermodynamic parameters using a kinetic modeling approach to describe the post-consumer poly(ethylene terephthalate) hydrolysis catalyzed by cutinase from Humicola insolens

Erika de Queiros Eugenio ${ }^{1,2}$, Ivone Sampaio Pereira Campisano ${ }^{1}$, Aline Machado de C astro ${ }^{3}$, Maria Alice Zarur Coelho ${ }^{1}$, Marta Antunes Pereira Langone ${ }^{4,5 *}$.

${ }^{1}$ School of Chemistry, Federal University of Rio de Janeiro (UFRJ), Rio de Janeiro, Brazil.

${ }^{2}$ Faculty of Technology, Rio de Janeiro State University (UERJ), Rio de Janeiro, Brazil.

${ }^{3}$ Biotechnology Division, Research, and Development Center, Petrobras, Rio de Janeiro, Brazil

${ }^{4}$ Chemistry Institute, Rio de Janeiro State University (UERJ), Rio de Janeiro, Brazil.

${ }^{5}$ Federal Institute of Education, Science, and Technology of Rio de Janeiro (IFRJ), Rio de Janeiro, Brazil.

\section{Corresponding author:}

Tel: 55212334 0563, Rio de Janeiro State University, Chemistry Institute Analytical Chemistry department, Fax: 552123340159

E-mail: marta.langone@gmail.com 


\begin{abstract}
The search for a straightforward technology for post-consumer poly(ethylene terephthalate) (PC-PET) degradation is essential to develop a circular economy. In this context, PET hydrolases such as cutinases can be used as bioplatforms for this purpose. Humicola insolens cutinase $(\mathrm{HiC})$ is a promising biocatalyst for PC-PET hydrolysis. Therefore, this work evaluated a kinetic model, and it was observed that the HiC seems not to be inhibited by any of the main PET hydrolysis products such as terephthalic acid (TPA), mono-(2-hydroxyethyl) terephthalate (MHET), and bis-(2-hydroxyethyl) terephthalate (BHET). The excellent fitting of the experimental data to a kinetic model based on enzyme-limiting conditions validates its employment for describing the enzymatic PC-PET hydrolysis using two-particle size ranges (0.075-0.250, and 0.250-0.600 mm) and temperatures (40, 50, 55, 60, 70, and $\left.80{ }^{\circ} \mathrm{C}\right)$. The Arrhenius law provided a reliable parameter (activation energy of $98.9 \pm 2.6 \mathrm{~kJ} \mathrm{~mol}^{-1}$ ) for enzymatic hydrolysis, which compares well with reported values for chemical PET hydrolysis. The thermodynamic parameters of PC-PET hydrolysis corresponded to activation enthalpy of $96.1 \pm 3.6 \mathrm{~kJ} \mathrm{~mol}^{-1}$ and activation entropy of $10.8 \pm 9.8 \mathrm{~J} \mathrm{~mol}^{-1} \mathrm{~K}^{-1}$. Thus, the observed rate enhancement with temperature was attributed to the enthalpic contribution, and this understanding is helpful to the comprehension of enzymatic behavior on hydrolysis reaction.
\end{abstract}

Keywords: PET biodegradation; Humicola insolens cutinase; Kinetic parameters; Heterogeneous biocatalysis. 


\section{Introduction}

Poly(ethylene terephthalate) (PET) is one of the significant plastics produced worldwide, and it is largely used for the packaging market and the textile industry. The annual global PET production is almost 70 million tons [1], and it is expected to increase over the years due to its great packaging demand [2]. As a consequence of this, an enormous amount of post-consumer PET (PC-PET) is discarded in inappropriate places or buried in landfills, and the minimization of such wastes have been focused countless efforts in order to implement a circular economy [3-6]. Some reports claim that bioremediation can help mitigate marine and terrestrial contamination [7, 8]. In this context, enzymatic catalysis, specifically the biodepolymerization process, dawns as one of the most promising technologies in a plastic circular economy. In the last decade, the use of esterases (EC 3.1.1.1) [9-11], lipases (EC 3.1.1.3) [12-18] and cutinases (EC 3.1.1.74) [14-21] as biocatalysts have been extensively investigated in an alternative eco-friendly route, the PET hydrolysis. Currently, cutinases from the thermophilic actinomycete Thermobifida fusca [22], from leaf-branch compost [1], from the thermophilic fungus Humicola insolens [21], and the mesophilic IsPETase cloned from Ideonella sakaienses [1, 23] show acceptable efficiency to degrade PET waste, such as packaging materials.

PET enzymatic hydrolysis is described as a heterogeneous reaction system in which the biocatalyst in an aqueous environment catalyzes with the insoluble and macroscopic polyester, containing highly ordered (crystalline) and less ordered (amorphous) regions [24], being the last ones more accessible. Therefore, PET erosion probably occurs similarly to cellulose degradation [24]. This phenomenon consists of chain disruption and loosening, making the individual substrate molecule more accessible and available for interactions with degrading enzymes [25]. Moreover, enzymatic hydrolysis of PET occurs with the generation of new free hydroxyl and carboxyl groups at the polymer surface through the cleavage of ester backbones, which results in increased PET hydrophilicity [26]. The resulting low molecular weight products of the enzymatic hydrolysis comprise ethylene glycol (EG), and terephthalic acid (TPA) that are the PET synthesis monomers, and beyond these, mono(2-hydroxyethyl) terephthalate (MHET), and bis(2-hydroxyethyl) terephthalate (BHET) that are the main intermediate reaction products.

The depolymerization of water-insoluble substrates using enzymes, such as cellulases, chitinases, xylanases, and depolymerases, occurs via two-steps: adsorption and hydrolysis. In 
the first moment occurs the adsorption of the enzyme on the hydrophobic surface of the substrate. The second step is the hydrolysis of the polymer chain at the active site of the enzyme [27]. Therefore, the hydrophobicity of the enzyme surface influences the interaction with hydrophobic polyesters [28]. Thus, enzymatic hydrolysis is a route for recycling PET waste that depends strongly on the substrate surface availability [29, 30].

The mobility of PET chains is also a relevant factor for the biodegradability of polyesters [31]. The chain mobility of the polymer is determined by the crystallinity of the polymer, and it increases at temperatures close to its glass transition temperature $\left(\mathrm{T}_{\mathrm{g}}\right)[26,32$, 33]. The increase of the reaction temperature of PET hydrolysis increases polymer chain flexibility, which favors the diffusion of water molecules between the polymer chains through the weakening of the hydrogen bonds, as well as randomizing and increasing the flexibility of the PET chain, thus, enhancing the enzyme accessibility to the ester bonds [26].

In light of the challenges mentioned above to describe PC-PET enzymatic hydrolysis, this study initially evaluated the stirring speed effect and the availability of the substrate concentration on the reaction rate. Thus, a kinetic analysis was performed through a model based on enzyme-limiting conditions to determine key-kinetic parameters, which are relevant for developing an industrial process of PET depolymerization. The product inhibition was also evaluated. Although some studies have suggested a mathematical approach to describe PET hydrolysis, to the best of our knowledge, none of them determined the activation parameters for this reaction. Therefore, the investigation of Humicola insolens cutinase (HiC) ability to undergo efficient catalysis is reported here over the temperature range of 40 to $80^{\circ} \mathrm{C}$. The aim of this study is not only to determine the kinetics of the enzymatic reaction but also to provide critical parameters that must be considered in the design of a scalable process.

\section{Materials and methods}

\subsection{Materials}

Terephthalic acid (TPA, purity 98\%) and bis-(2-hydroxyethyl) terephthalate (BHET, purity 99.8\%) were purchased from Sigma-Aldrich. Mono-(2-hydroxyethyl) terephthalate (MHET) was synthesized by our group through the enzymatic hydrolysis of BHET. The 
commercial liquid preparation with Humicola insolens cutinase (product Novozym® 51032) was kindly provided by Novozymes (Araucária, Brazil).

The post-consumer PET (PC-PET) was originated in an industrial mechanical recycling plant and was composed of different (i.e., different thicknesses, colors, etc.) packages. The PCPET presented high crystallinity $(41.1 \%)$ and high molar mass $\left(43,379 \mathrm{~g} \mathrm{~mol}^{-1}\right)$, as described by Castro and collaborators [18]. The material was received as flakes, grinded in a knife mill, and sieved into two fractions with different granulometric size ranges: F1: 0.075-0.250 mm, and F2: $0.250-0.600 \mathrm{~mm}$.

\subsection{Quantification of the enzymatic hydrolysis products}

The quantification of TPA, MHET, and BHET concentrations was carried out in a Waters High-Performance Liquid Chromatograph equipped with a binary pump (1525 model), and a UV/Visible detector (2489 model) at $254 \mathrm{~nm}$ wavelength. The injection volume employed was $20 \mu \mathrm{L}$, and the column, an Eclipse Plus C18 column (Agilent Technologies), of $4.6 \mathrm{~mm} \times 250 \mathrm{~mm}$ and $5 \mu \mathrm{m}$ particle diameter, was kept at $30{ }^{\circ} \mathrm{C}$. The analysis methodology was performed using a gradient elution method, and the mobile phases used were acetonitrile and an aqueous solution of formic acid (0.05 vol.\%) under a total flow rate of $0.500 \mathrm{~mL} \mathrm{~min}{ }^{-1}$. The TPA, MHET, and BHET concentrations were determined based on standard curves.

\subsection{Enzymatic characterization}

The protein concentration of $\mathrm{HiC}$ commercial liquid preparation was determined according to the Bradford method [34], and the obtained result was $16.8 \mathrm{mg} \mathrm{mL}^{-1}$. The polyacrylamide gel electrophoresis analysis in the presence of sodium dodecyl sulphate (SDSPAGE) indicated that the predominant protein of HiC preparation has a molar mass of around $18 \mathrm{kDa}$.

The hydrolytic activity of $\mathrm{HiC}$ was assessed as the BHET hydrolysis capacity, releasing MHET and ethylene glycol, in $200 \mathrm{mmol} \mathrm{L}^{-1}$ phosphate buffer, $\mathrm{pH}$ 7.0. The reaction was carried out in a $50 \mathrm{~mL}$ glass reaction vessel with mechanic stirring (EasyMax ${ }^{\mathrm{TM}} 102$, Mettler Toledo) with an initial BHET concentration of $8 \mathrm{mmol} \mathrm{L}^{-1}$ and enzyme concentration of $0.05 \mathrm{~g}_{\text {protein }}$ 
$\mathrm{g}_{\mathrm{BHET}}{ }^{-1}$ at $40^{\circ} \mathrm{C}$. The reaction was monitored by the quantification of TPA, MHET, and BHET by HPLC, according to the methodology described in item 2.2. One unit of activity was defined as the amount ( $\mu \mathrm{mol})$ of MHET formed per minute, and the result obtained for HiC specific activity was $1.9 \pm 0.2 \mathrm{U} \mathrm{mg}_{\text {protein }}{ }^{-1}$. The enzyme activity remained constant during all the experiments.

\subsection{PET hydrolysis}

The PC-PET hydrolysis was carried out in a $10 \mathrm{~mL}$ reactor provided with magnetic stirring (EasyMax ${ }^{\mathrm{TM}}$ 102, Mettler Toledo), employing HiC as a biocatalyst diluted in phosphate buffer solution. All tests were carried out using $200 \mathrm{mmol} \mathrm{L}^{-1}$ phosphate buffer ( $\mathrm{pH}$ 7.0), and $\mathrm{HiC}$ concentration of $1.0 \mathrm{mg}_{\text {protein }} \mathrm{mL}^{-1}$. At appropriate intervals, samples of the reaction medium were withdrawn and diluted in methanol before chromatographic analysis. The sum of the TPA, MHET, and BHET concentrations was used to determine the initial reaction rates.

The TPA yield was defined as described in Equation 1, where [TPA] and [PET $]_{0}$ refer to the concentration of TPA and the initial concentration of PET on mass basis $\left(\mathrm{g} \mathrm{L}^{-1}\right)$, respectively. $M_{T P A}$ and $M_{P E T}$ are the molar mass of TPA $\left(166.1 \mathrm{~g} \mathrm{~mol}^{-1}\right)$ and the PET repeat unit $\left(192.2 \mathrm{~g} \mathrm{~mol}^{-1}\right)$, respectively [35].

$$
T P A \operatorname{Yield}(\%)=\frac{[T P A]}{[P E T]_{0} / M_{T P A}} \times 100
$$

\subsubsection{Effect of substrate concentration on PET hydrolysis}

The effect of PET concentration on the enzymatic hydrolysis was evaluated using different PET concentrations: 10, 35, 50, 80, 100, 120, 150, 200, 220, $250 \mathrm{~g} \mathrm{~L}^{-1}$. For all assays, the reactor stirring speed was $800 \mathrm{rpm}$, and the reaction temperature was kept at $70^{\circ} \mathrm{C}$.

\subsubsection{Effect of stirring speed}

The diffusion effect was studied under three different stirring speeds: 100, 400, and 800 $\mathrm{rpm}$, and various substrate concentrations $\left(10,35,50,80,100,120,150,200,220,250 \mathrm{~g} \mathrm{~L}^{-1}\right)$, at $70^{\circ} \mathrm{C}$. 


\subsubsection{Kinetic study of enzymatic PET hydrolysis and product inhibition}

Barth and collaborators [30] proposed a model for the heterogeneous enzymatic PET hydrolysis. The following assumptions were made in order to simplify the mathematical representation [36]:

- Considering that the catalytic site of $\mathrm{HiC}$ has the unique function of producing oligomers that can be represented as the product $(\mathrm{P})$, the resulting system could be modeled analyzing only the hydrolysis and adsorption steps with no incorporation of an extra kinetic parameter.

- The substrate concentration is based on the surface concentration accessible to enzymes for adsorption and subsequent catalysis, which considers the effect of substrate particle size.

- The produced oligomers may inhibit the biocatalyst reversibly and competitively, forming an EP complex.

Based on these assumptions, the heterogeneous enzymatic PET hydrolysis can be described by the following reaction scheme:

$$
\begin{aligned}
& k_{a} \\
& E+S \underset{k_{d}}{\stackrel{k_{a}}{\leftrightharpoons}} E S \stackrel{k}{\rightarrow} P+E \\
& \beta_{1} \\
& E+P \leftrightharpoons P E \\
& \beta_{2}
\end{aligned}
$$

First, the free enzyme (E) adsorbs to the PET surface. Then, the adsorbed enzyme binds to available ester bonds on the PET surface, forming an enzyme-substrate surface (ES). Finally, the enzyme catalyzes the polyester hydrolysis and releases the product $(\mathrm{P})$. The free enzyme (E) can also bind to the released products becoming briefly unavailable to bind the PET substrate. The forward and reverse reaction rate constants of the formation of the enzymesubstrate complex are $k_{a}$ and $k_{d}$, respectively. $k$ is the rate constant of product formation, and $\beta_{1}$ and $\beta_{2}$ are binding constants for products. According to the proposed reaction scheme, the concentration of the enzyme-substrate complex (ES) can be expressed by Equation 4. Thus, defining the total enzyme concentration (Equation 5) and an adsorption equilibrium constant in terms of the amount of enzyme bound to the substrate ( $K$, Equation 6$)$ or the products $(\beta$, Equation 7), it was possible to rearrange the equations and define the initial rate as expressed in Equation 8. 


$$
\begin{aligned}
& {[E S]=\frac{K\left[E_{0}\right][S]}{1+\beta[P]+K[S]}} \\
& {\left[E_{0}\right]=[E]+[E S]+[E P]} \\
& K=\frac{k_{a}}{k_{d}}=\frac{[E S]}{[E][S]} \\
& \beta=\frac{\beta_{1}}{\beta_{2}}=\frac{[E P]}{[E][P]} \\
& v=\frac{d(P)}{d t}=k[E S]=k\left[E_{0}\right] \frac{K[S]}{(1 / i)+K[S]}
\end{aligned}
$$

where $i$ is the inhibition parameter that can be described for each product formed (P) as shown in Equation 9.

$$
\frac{1}{i}=1+\beta[P]
$$

If the product did not interact with the enzyme, then $\beta$ tends to 0 ; that is, no competitive inhibitory effect is evidenced, and therefore Equation 8 can be rewritten as described in Equation 10.

$$
v=k\left[E_{0}\right] \frac{K[S]}{1+K[S]}
$$

The kinetic model was adjusted for two different granulometric size ranges in order to test its validity to describe PET hydrolysis. Analysis of specific surface area of selected PET samples was performed in a Mastersizer 2000 analyzer (Malvern Instruments).

The product inhibition was investigated by adding a defined amount of PET hydrolysis products (TPA, MHET, and BHET) to the reaction mixture. After equilibration for $10 \mathrm{~min}$ at $70{ }^{\circ} \mathrm{C}$, the $\mathrm{HiC}$ was added to the reaction medium. The effect of TPA inhibition was evaluated using TPA concentrations of 10 and $20 \mathrm{mmol} \mathrm{L}^{-1}$. The analysis of MHET as an inhibitor was performed through PET hydrolysis employing MHET concentrations of 5, 10, 15, and $20 \mathrm{mmol}$ $\mathrm{L}^{-1}$. A similar investigation was conducted with BHET concentrations of 2, 10, 20, 30, and 40 $\mathrm{mmol} \mathrm{L}{ }^{-1}$. Reactions were carried out at $70{ }^{\circ} \mathrm{C}$ with an initial PET concentration of $50 \mathrm{~g} \mathrm{~L}^{-1}$ with a particle diameter range of $0.075-0.250 \mathrm{~mm}$, and under $800 \mathrm{rpm}$ stirring speed 


\subsubsection{Effect of temperature}

The reactions were carried out at six temperatures $\left(40,50,55,60,70\right.$ and $\left.80{ }^{\circ} \mathrm{C}\right)$, and initial PET concentrations of 10, 35, 50, 80, 100, 120, 150, 200, 220, $250 \mathrm{~g} \mathrm{~L}^{-1}$. The enzymatic reaction rate $(k)$ was determined as described in Equation 8, at each temperature. Therefore, the temperature dependence of rate constants was calculated through Arrhenius (Equation 11) and Eyring-Polanyi (Equation 12) equations. The Arrhenius constant $\left(A_{0}\right)$ and the activation energy $\left(E_{a}\right)$ were determined using a gas constant $(R)$ of $8.314 \mathrm{~J} \mathrm{~mol}^{-1} \mathrm{~K}^{-1}$. The enthalpy $\left(\Delta H^{\#}\right)$ and entropy $\left(\Delta S^{\#}\right)$ of activation were estimated from derived Eyring-Polanyi equation assuming that the transmission coefficient ( $\kappa$ ) is equal to 1 , for monomolecular reactions [37], and that Boltzmann $\left(k_{B}\right)$ and Planck $(h)$ constants are equal to $1.38 .10^{-23} \mathrm{~J} \mathrm{~K}^{-1}$ and $6.62 .10^{-34} \mathrm{~J} \mathrm{~s}$, respectively.

$$
\begin{aligned}
& k=A_{0} e^{-\frac{E_{a}}{R T}} \\
& k=\frac{\kappa k_{B}}{h} T e^{\frac{\Delta S^{\#}}{R}} e^{-\frac{\Delta H^{\#}}{R T}}
\end{aligned}
$$

The parameters of the non-linear kinetic model and all the activation parameters were obtained by numerical estimation using the Levenberg-Marquardt algorithm. The data were analyzed by Origin 8.1 software using the convergence criterion of chi-square minimization (tolerance of $10^{-9}$ ) and the maximum number of iterations equal to 50 .

\section{Results and discussion}

\subsection{Effect of PC-PET concentration on enzymatic hydrolysis}

The enzymatic degradation of PET is a heterogeneous catalytic process, in which the reactant is not solvated in the bulk solution. The effectiveness of enzymes is sensitive by continuous enzyme-substrate-product interactions at the PET-water reaction interface, such as enzyme binding, desorption, inhibition, and diffusion [36], and all these phenomena can cause remarkable changes of substrate exposed area. Thus, the effect of substrate concentration (10 $-250 \mathrm{~g} \mathrm{~L}^{-1}$ ) on the concentration of PET hydrolysis products was investigated, and Figure 1 represents the results obtained. The PET hydrolysis products (TPA, MHET, and BHET) concentration had the lowest value at $10 \mathrm{~g} \mathrm{~L}^{-1}$, while the maximum product concentration 
(129.42 $\mathrm{mmol} \mathrm{L}^{-1}$ ) was obtained with $220 \mathrm{~g} \mathrm{~L}^{-1}$ of PET after 96h. Moreover, a higher concentration of released products after $96 \mathrm{~h}$ was observed than reported for Carniel and collaborators [17] after 14 days of reaction using $\mathrm{HiC}$ at $60{ }^{\circ} \mathrm{C}$, and higher than measured for Gamerith and collaborators [38] after 21 days of enzymatic hydrolysis using Thermobifida cellulosilytica cutinase at $50^{\circ} \mathrm{C}$, in almost the same enzyme concentration.

\section{Figure 1}

The results showed that higher substrate concentrations appear to have two positive effects, as expected, (i) faster initial reaction rate and (ii) higher product generation. However, the positive effects of high substrate concentration, concerning the products released, decreased for PET concentrations above $220 \mathrm{~g} \mathrm{~L}^{-1}$. It seems that interactions between reactants and biocatalysts occur quite differently from their homogenous counterparts, indicating that the diffusion processes in two- or one-dimensional space occur differently [39]. Therefore, the mass transfer limitation was evaluated varying the reaction stirring speed. A more intensive mixing regime should facilitate a better mass transfer inside the reactor, being effective to reduce a potentially high local product concentration surrounding the enzyme active site [36].

\subsection{Effect of stirring speed}

The enzymatic PET hydrolysis system is composed of a liquid phase, containing enzymatic extract, and a solid phase consisted of the PET particles. An adequate interaction of the enzyme with the substrate at the solid-liquid interface is essential for efficient enzymatic PET hydrolysis [40]. Therefore, the rate of PET hydrolysis could be affected by diffusion limitations. According to Gan and collaborators [36], the heterogeneous hydrolytic reaction rate is determined by three events in a stirred batch reactor. The first one is the mass enzyme transfer through the stagnant liquid film layer adjacent to the solid substrate, the second event refers to the enzyme adsorption at the substrate surface, and finally, the third one is the catalysis. Thus, with the progress of the enzymatic PET hydrolysis, the amount of available substrate decreases, and the overall reaction rate depends on the enzyme penetration and diffusion inside the solid substrate. 
The effect of stirring speed on the PET hydrolysis reaction was investigated with the varying initial concentration of PC-PET (10 to $\left.250 \mathrm{~g} \mathrm{~L}^{-1}\right)$ and stirring reaction speed (100, 400, and $800 \mathrm{rpm})$.

\section{Figure 2}

According to the results shown in Figure 2, the reactor stirring speeds of 400 and 800 rpm resulted in an efficient interfacial mass transfer with no diffusion restriction for reactions conducted with PC-PET concentrations of up to $150 \mathrm{~g} \mathrm{~L}^{-1}$. However, when the substrate concentration was higher than $150 \mathrm{~g} \mathrm{~L}^{-1}$, a large difference between the initial rates obtained under 400 and $800 \mathrm{rpm}$ stirring speed was observed, suggesting a stronger influence of mass transfer contribution compared to the kinetic one. The increase of the initial substrate concentration to $200 \mathrm{~g} \mathrm{~L}^{-1}$ increased of TPA yield $(2.9,3.5$, and $4.9 \%)$ with the reactor stirring speed enhancement (100, 400, and $800 \mathrm{rpm}$, respectively). For all experiments conducted under different stirring speeds, the best result was obtained for $220 \mathrm{~g} \mathrm{~L}^{-1}$ PC-PET under a stirring speed of $800 \mathrm{rpm}$ that resulted in a TPA yield of $9.2 \%$ after $96 \mathrm{~h}$, which corresponds to 105.62 mmol L ${ }^{-1}$ of TPA released.

For the three series of experiments, the initial product formation rate goes through a maximum, corroborating the limited enzyme diffusion into substrate surface for PC-PET concentrations above this maximum. As the reactor stirring speed decreases, a thicker boundary layer around solid particle surfaces increases, resulting in a higher mass transfer resistance in the external film of the solid [41]. Such behavior was observed in the PET enzymatic hydrolysis conducted at $100 \mathrm{rpm}$, in which lower initial rates were noted for all substrate concentrations.

The PET enzymatic hydrolysis has similar aspects to the hydrolysis of other polymers as cellulose [24, 30]. Ingesson and collaborators [42] studied the enzymatic hydrolysis of cellulose and they reported that an increase of $7.5 \%$ on the initial substrate concentration resulted in the reduction of the initial hydrolysis rate and the conversion yield for different shaking regimes (reaction flasks were shaken continuously or intermittently). The authors attributed this behavior to end-product inhibition and mass transfer limitations within the reaction mixture due to the high viscosity of the slurry (reaction medium).

Thus, considering that the best results were obtained for reactions carried out at 800 rpm stirring speed, further experiments were conducted with the same stirring speed to 
minimize the diffusion restriction for the kinetic study and to evaluate the enzyme inhibition by hydrolysis products.

\subsection{Effect of PC-PET concentration: Kinetic study}

The enzymatic hydrolysis of PET is influenced by product inhibition [43]. The watersoluble hydrolysis products, MHET and BHET, are reported in the literature as competitive inhibitors of cutinases from Thermobifida species [30, 38, 43]. These products and PET compete for the active site responsible for the occurrence of the enzymatic reaction. Thus, some experiments were performed by supplying an initial amount of BHET, MHET, and TPA to the PC-PET hydrolysis medium reaction to analyze the product inhibition.

Figure 3 shows that the sum of the hydrolysis product concentration released from the PC-PET varied essentially linearly with the amount of TPA, MHET, or BHET added to the reaction medium. The lack of $\mathrm{HiC}$ inhibition by BHET, MHET, and TPA evidences an excellent feature for a future scale-up of a bioprocess using a single enzymatic system. This approach could reduce the cost and the complexity of reactor design or operation [44], once multi-enzyme systems could be limited concerning different optimal activity ranges and deactivation kinetics [45].

\section{Figure 3}

The kinetics of PC-PET hydrolysis catalyzed by HiC was studied by employing a heterogeneous model based on enzyme-limiting conditions proposed by Barth and collaborators [Barth, 2015]. Even though cutinases from Thermobifida sp. present a competitive inhibition effect by reaction products [30, 38, 43], the cutinase from Humicola insolens seems not to be inhibited at $70^{\circ} \mathrm{C}$ by any of PET products, which suggests that the enzyme could be used in its maximum activity. Thus, by adjusting the model, the inhibitor contribution term $(\beta)$ was considered equal to 0 , since there was no inhibition contribution, and then, it was possible to determine the reaction constants through Equation 10.

The reaction rates were determined from the sum of released hydrolysis product concentrations in the reactions with different initial PET concentrations, and it was plotted as a function of substrate concentration for two PC-PET granulometric size ranges (Figure 4). 
high determination coefficient $\left(\mathrm{R}^{2}\right)$ was obtained in the fitting to the kinetic model given by Equation 10, which was superior to 0.978 for both ranges, thereby confirming the model validity. The kinetic parameters were obtained by nonlinear regression analysis, and the results are presented in Table 1.

\section{Figure 4}

\section{Table 1}

The PC-PET fraction with the smaller particle size range $\left(\mathrm{F}_{1}\right)$ presented a larger specific area than $F_{2}$ (Table 1), which means a higher substrate surface area available. Therefore, the reaction carried out with the smallest PET particles showed a 2.4-fold higher hydrolysis rate constant $(\mathrm{k})$ than the larger particle size range $\left(\mathrm{F}_{2}\right)$. This is expected, as the enzymatic PET hydrolysis occurs in a heterogeneous interface, and PET erosion depends on substrate surface availability. Similar behavior was also observed in other studies [46, 47], in which the decreasing particle size led to higher PET depolymerization due to increased surface area. Besides, comparable adsorption equilibrium constants (K) were obtained for both PCPET particle size ranges by analyzing them based on initial substrate concentration. On the other hand, the value of $\mathrm{K}\left(0.0051 \mathrm{~mL} \mathrm{~cm}^{-2}\right)$ estimated for the $\mathrm{F} 1$ range, based on the PC-PET surface area, was 6.6-fold lower than that obtained for $F_{2}\left(0.0339 \mathrm{~mL} \mathrm{~cm}^{-2}\right)$, which is almost equal to the specific area ratio between $F_{1}$ and $F_{2}$. Therefore, it can be suggested that the accessibility of the degradable ester bonds for different substrate particle sizes was not significantly affected by enzyme affinity to PET, differently from what was seen when PET samples with different crystallinities were evaluated [40].

The proposed kinetic model was able to describe PC-PET erosion since this reaction depends on the substrate surface availability. Thus, different temperatures were also evaluated using this model to investigate this effect on enzymatic PET hydrolysis, which is relevant to take into account in bioreactor design and further scaling-up strategies to implement the enzymatic PET hydrolysis route.

\subsection{Effect of temperature}


It is well known that temperature significantly affects the hydrolysis of PC-PET [20, 38,48 ]. Cutinases must be thermally stable (at temperatures above $60^{\circ} \mathrm{C}$ ) for the hydrolysis of semi-crystalline PET [33, 49-51]. Such behavior is necessary because the mobility of the polymer chain increases above the glass transition temperature $\left(\mathrm{T}_{\mathrm{g}}\right)$, which for PC-PET occurs at $78.5^{\circ} \mathrm{C}$ [52] but it may be lowered by approximately $10{ }^{\circ} \mathrm{C}$ in aqueous solutions $[53,54]$.

The temperature effect on the hydrolysis rate was addressed in this work through Arrhenius law in order to seek the best temperature range to use the HiC. Thus, several PCPET concentrations were evaluated at each temperature $\left(40,50,55,60,70\right.$, and $\left.80{ }^{\circ} \mathrm{C}\right)$, and the heterogeneous kinetic model was adjusted, as shown in Figure 5. An increase in the initial rate was observed with the rise of temperature, except at $80{ }^{\circ} \mathrm{C}$. The highest hydrolysis rate was observed at $70{ }^{\circ} \mathrm{C}$, closer to the $\mathrm{T}_{\mathrm{g}}$ of PET, where chain mobility of the polymer is higher. Probably, the temperature of $80^{\circ} \mathrm{C}$ led to enzymatic denaturation, even though the literature reports that the optimum temperature range is between 75 and $80{ }^{\circ} \mathrm{C}$ for the hydrolysis of PET using $\mathrm{HiC}[20,32]$.

\section{Figure 5}

It can be seen from Figure 5 and Table 2 that the kinetic model was able to describe the data with a good statistical agreement for all temperatures studied, as indicates the $\mathrm{R}^{2}$ values, that were higher than 0.949 in all cases. The worst adjustments were observed at the lowest temperatures $\left(40\right.$ and $50{ }^{\circ} \mathrm{C}$ ), which can be attributed to the gap between the reaction temperature and the $\mathrm{T}_{\mathrm{g}}$. The hydrolysis of PC-PET showed a 2.4-fold higher hydrolysis rate constant (k) and maintained a similar value of adsorption equilibrium constants $(\mathrm{K})$ by increasing the reaction temperature from $60^{\circ} \mathrm{C}$ to $70^{\circ} \mathrm{C}$. On the other hand, an extremely pronounced effect was observed by reducing the reaction temperature from $70{ }^{\circ} \mathrm{C}$ to $55^{\circ} \mathrm{C}$, diminishing the reaction rate by about $78.6 \%$, which can be explained in the light of the low mobility of the polymer at $55{ }^{\circ} \mathrm{C}$. The adsorption constant (K) decreases moderately with the increase of temperature, as expected, indicating stronger enzyme adsorption at lower temperatures. These results show that the reaction rate constant $(\mathrm{k})$ has a stronger influence on the overall reaction rate than the adsorption equilibrium constant $(\mathrm{K})$, as reported by Basu and collaborators [55].

\section{Table 2}


The availability of thermodynamic reaction parameters is of interest in investigating the structure-reactivity relationship [37]. The enzymatic reaction starts with the initial binding of a substrate by an enzyme, and then, it proceeds by increasing their mutual affinity in water, which leads to a rate enhancement [56]. The enzyme binding interactions include fixation of the reacting groups of the substrate at the active site in the correct position and a destabilization of the ground state that brings a considerable loss of entropy, thus decreasing the activation energy of the reaction [57]. As the enzyme conformation changes during the catalytic event, it would be useful to study structures approaching the transition state of the biocatalyzed reaction. The transition state itself is too short-lived, but an indirect approach, such as Pauling's transition state stabilization theory, may provide a partial solution to this problem [58]. This theory proposes that enzymes are developed to bind tightly to the transition state rather than the reactant or product. The high affinity of the enzyme active site by transition state results in lowering the activation state.

An exponential approach was adopted to determine the activation parameters, and the results are shown in Figure 6 and Table 3. The activation energy $\left(E_{a}\right)$ and Arrhenius constant $\left(A_{0}\right)$ were obtained by the Arrhenius equation (Equation 11) through estimated values of the reaction rate constant, and the correlation coefficient of the nonlinear regression was 0.998 . The excellent fit of the data to the Arrhenius equation confirms that the kinetic model, estimated from different substrate concentrations, was adequate to describe the enzymatic hydrolysis of PET. The apparent activation energy found for PC-PET hydrolysis using $\mathrm{HiC}$ was $98.9 \pm 2.6$ $\mathrm{kJ} \mathrm{mol}^{-1}$. This $\mathrm{E}_{\mathrm{a}}$ value obtained for enzymatic hydrolysis of PC-PET has the same order of magnitude as other chemical catalytic routes. Carta and collaborators [59] evaluated the recycling of PET through neutral hydrolysis by fitting an autocatalytic model of half-order, and they found activation energy of $123 \mathrm{~kJ} \mathrm{~mol}^{-1}$, while the PET hydrolysis using a dual functional phase transfer catalyst resulted in lower activation energy $\left(63 \mathrm{~kJ} \mathrm{~mol}^{-1}\right)$ at a temperature range of $115-145^{\circ} \mathrm{C}[60]$. The literature reports similar values of activation energy for acid-hydrolysis $\left(100-110 \mathrm{~kJ} \mathrm{~mol}^{-1}\right)[61,62]$ and neutral hydrolysis $\left(90-123 \mathrm{~kJ} \mathrm{~mol}^{-1}\right)$ of PET [63, 64].

Two contributions can describe the overall activation free energy $\left(\Delta G^{\#}=\Delta H^{\#}-T \Delta S^{\#}\right)$, one referring to the entropy of activation $\left(-\mathrm{T} \Delta \mathrm{S}^{\#}\right)$ while the other to the heat one $\left(\Delta \mathrm{H}^{\#}\right)$ [Aqvist, 2017]. Thus, the estimation of both parameters was performed using the Eyring-Polonyi equation (Equation 12) rate, and the values estimated for $\Delta H^{\#}$ and $\Delta S^{\#}$ were equal to $96.1 \pm 3.6$ $\mathrm{kJ} \mathrm{mol}^{-1}$ and $10.8 \mathrm{~J} \pm 9.8 \mathrm{~mol}^{-1} \mathrm{~K}^{-1}$, respectively. Wolfenden and collaborators [65] observed that $\Delta \mathrm{S}^{\#}$ is low for hydrolytic reactions, and on the other hand, $\Delta \mathrm{H}^{\#}$ is high and positive for 
slow reactions that are catalyzed by enzymes. Besides, the entropy contribution (-T $\left.\Delta \mathrm{S}^{\#}\right)$ implies that the degree of randomness decreases with the adsorption [55] of the enzyme. As both phenomena occur simultaneously, the adsorption step is followed by a considerable release of enthalpy, which results from the increase in substrate affinity by the enzyme [56].

The Circe effect hypothesis postulates that enzymes spend some part of the binding free energy on binding tightly to the substrate [57]. Thus, the reaction progress, that is, the ES complex shifting from the ground state to the transition state, is mainly enthalpic in its origin [56]. It was reported that enthalpy tends to dominate the enzyme thermodynamics on reactions involving single substrates and hydrolytic reactions in which water is present in abundance [65]. Therefore, the activation barrier can be climbed without any entropy loss, producing an increase in the enzymatic reaction rate [66].

\section{Figure 6}

\section{Table 3}

Thus, the estimation of thermodynamic activation parameters for PC-PET hydrolysis allowed the understanding of the origin of enthalpic contributions to enzymatic rate enhancement. This comprehension will be useful for rationalizing further enzymological experiments on PC-PET hydrolysis and enzyme (HiC) engineering and design.

\section{Conclusion}

The kinetic study of post-consumer PET (PC-PET) hydrolysis was performed based on enzyme-limiting conditions under a stirring speed of $800 \mathrm{rpm}$ to avoid diffusion restriction, based on preliminary obtained data. The inhibition effect of HiC by the main PET hydrolysis products (TPA, MHET, and BHET) was evaluated at $70{ }^{\circ} \mathrm{C}$, and no inhibition evidence was observed, which suggests that the potential of the enzyme can be used at its maximum. This represents a promising aspect for future evaluations since there is no necessity of incorporating strategies to circumvent inhibition problems, such as the employment of a multi-enzymatic system. The excellent agreement between experimental data and a model based on enzymelimiting conditions validates its use for describing the enzymatic hydrolysis of PC-PET with different granulometric size ranges and temperatures. The reaction rate constant increased by an exponential factor with the reaction temperature enhancement, except at $80^{\circ} \mathrm{C}$, which may 
have been caused by enzymatic denaturation. The activation energy was determined through the Arrhenius equation with an excellent adjustment $\left(\mathrm{R}^{2}=0.998\right)$, and the value obtained for enzymatic hydrolysis had the same order of magnitude as those parameters reported in the literature for chemical PET hydrolysis. Thermodynamic parameters obtained for enzymatic PC-PET hydrolysis were found to have an activation enthalpy of $96.1 \pm 3.6 \mathrm{~kJ} \mathrm{~mol}^{-1}$ and activation entropy of $10.8 \pm 9.8 \mathrm{~J} \mathrm{~mol}^{-1} \mathrm{~K}^{-1}$. Kinetic correlations provided a reliable mathematical model of the heterogeneous hydrolysis of PC-PET using $\mathrm{HiC}$ as biocatalyst, providing a significant amount $\left(105.62 \mathrm{mmol} \mathrm{L}^{-1}\right)$ of released TPA, which can benefit the implementation of a circular economy.

\section{Acknowledgments}

The authors thank UFRJ, UERJ, IFRJ, and Petrobras for funding. The authors thank the Professor Marcos Lopes Dias of the Federal University of Rio de Janeiro for kindly providing PC-PET in powder form. 


\section{Reference}

1. Tournier V, Topham CM, Gilles A, et al (2020) An engineered PET depolymerase to break down and recycle plastic bottles. Nature 580:216-219. https://doi.org/10.1038/s41586-020-2149-4

2. Silva C, Cavaco-Paulo A, Nierstrasz VA (2010) Enzymatic hydrolysis and modification of core polymer fibres for textile and other applications. Adv Text Biotechnol 77-97. https://doi.org/10.1533/9780857090232.2.77

3. Sinha V, Patel MR, Patel J V. (2010) Pet waste management by chemical recycling: A review. J Polym Environ 18:8-25. https://doi.org/10.1007/s10924-008-0106-7

4. WEF (2016) The New Plastics Economy Rethinking the future of plastics. In: Physical Review B - Condensed Matter and Materials Physics

5. Taniguchi I, Yoshida S, Hiraga K, et al (2019) Biodegradation of PET: Current Status and Application Aspects. ACS Catal 9:4089-4105. https://doi.org/10.1021/acscatal.8b05171

6. Brouwer MT, Thoden van Velzen EU, Augustinus A, et al (2018) Predictive model for the Dutch post-consumer plastic packaging recycling system and implications for the circular economy. Waste Manag 71:62-85. https://doi.org/10.1016/j.wasman.2017.10.034

7. Hiraga K, Taniguchi I, Yoshida S, et al (2019) Biodegradation of waste PET . EMBO Rep 20:1-5. https://doi.org/10.15252/embr.201949365

8. Sheth MU, Kwartler SK, Schmaltz ER, et al (2019) Bioengineering a Future Free of Marine Plastic Waste. Front Mar Sci 6:1-10. https://doi.org/10.3389/fmars.2019.00624

9. Alisch M, Feuerhack A, Müller H, et al (2004) Biocatalytic modification of polyethylene terephthalate fibres by esterases from actinomycete isolates. Biocatal Biotransformation 22:347-351. https://doi.org/10.1080/10242420400025877

10. Billig S, Oeser T, Birkemeyer C, Zimmermann W (2010) Hydrolysis of cyclic poly(ethylene terephthalate) trimers by a carboxylesterase from Thermobifida fusca KW3. Appl Microbiol Biotechnol 87:1753-1764. https://doi.org/10.1007/s00253-0102635-y

11. Ribitsch D, Acero EH, Greimel K, et al (2012) A new esterase from Thermobifida halotolerans hydrolyses polyethylene terephthalate (PET) and polylactic acid (PLA). Polymers (Basel) 4:617-629. https://doi.org/10.3390/polym4010617

12. Vertommen MAME, Nierstrasz VA, Veer M Van Der, Warmoeskerken MMCG (2005) Enzymatic surface modification of poly(ethylene terephthalate). J Biotechnol 120:376-386. https://doi.org/10.1016/j.jbiotec.2005.06.015

13. Müller RJ, Schrader H, Profe J, et al (2005) Enzymatic degradation of poly(ethylene terephthalate): Rapid hydrolyse using a hydrolase from T. fusca. Macromol Rapid Commun 26:1400-1405. https://doi.org/10.1002/marc.200500410

14. Heumann S, Eberl A, Pobeheim H, et al (2006) New model substrates for enzymes hydrolysing polyethyleneterephthalate and polyamide fibres. J Biochem Biophys Methods 69:89-99. https://doi.org/10.1016/j.jbbm.2006.02.005

15. Eberl A, Heumann S, Brückner T, et al (2009) Enzymatic surface hydrolysis of poly(ethylene terephthalate) and bis(benzoyloxyethyl) terephthalate by lipase and cutinase in the presence of surface active molecules. J Biotechnol 143:207-212. 
https://doi.org/10.1016/j.jbiotec.2009.07.008

16. Herrero Acero E, Ribitsch D, Dellacher A, et al (2013) Surface engineering of a cutinase from Thermobifida Cellulosilytica for improved polyester hydrolysis. Biotechnol Bioeng 110:2581-2590. https://doi.org/10.1002/bit.24930

17. Carniel A, Valoni É, Nicomedes J, et al (2017) Lipase from Candida antarctica (CALB) and cutinase from Humicola insolens act synergistically for PET hydrolysis to terephthalic acid. Process Biochem 59:84-90. https://doi.org/10.1016/j.procbio.2016.07.023

18. de Castro AM, Carniel A, Nicomedes Junior J, et al (2017) Screening of commercial enzymes for poly(ethylene terephthalate) (PET) hydrolysis and synergy studies on different substrate sources. J Ind Microbiol Biotechnol 44:835-844. https://doi.org/10.1007/s10295-017-1942-z

19. Araújo R, Silva C, O’Neill A, et al (2007) Tailoring cutinase activity towards polyethylene terephthalate and polyamide 6,6 fibers. J Biotechnol 128:849-857. https://doi.org/10.1016/j.jbiotec.2006.12.028

20. Ronkvist ÅM, Xie W, Lu W, Gross RA (2009) Cutinase-Catalyzed hydrolysis of poly(ethylene terephthalate). Macromolecules 42:5128-5138.

https://doi.org/10.1021/ma9005318

21. Castro AM de, Carniel A, Stahelin D, et al (2019) High-fold improvement of assorted post-consumer poly(ethylene terephthalate) (PET) packages hydrolysis using Humicola insolens cutinase as a single biocatalyst. Process Biochem 81:85-91. https://doi.org/10.1016/j.procbio.2019.03.006

22. Furukawa M, Kawakami N, Tomizawa A, Miyamoto K (2019) Efficient Degradation of Poly(ethylene terephthalate) with Thermobifida fusca Cutinase Exhibiting Improved Catalytic Activity Generated using Mutagenesis and Additive-based Approaches. Sci Rep 9:1-9. https://doi.org/10.1038/s41598-019-52379-z

23. Liu C, Shi C, Zhu S, et al (2019) Structural and functional characterization of polyethylene terephthalate hydrolase from Ideonella sakaiensis. Biochem Biophys Res Commun 508:289-294. https://doi.org/10.1016/j.bbrc.2018.11.148

24. Krueger MC, Harms H, Schlosser D (2015) Prospects for microbiological solutions to environmental pollution with plastics. Appl Microbiol Biotechnol 99:8857-8874. https://doi.org/10.1007/s00253-015-6879-4

25. Arantes V, Saddler JN (2010) Access to cellulose limits the efficiency of enzymatic hydrolysis: The role of amorphogenesis. Biotechnol Biofuels 3:1-11. https://doi.org/10.1186/1754-6834-3-1

26. Kawai F, Kawabata T, Oda M (2019) Current knowledge on enzymatic PET degradation and its possible application to waste stream management and other fields. Appl Microbiol Biotechnol 103:4253-4268. https://doi.org/10.1007/s00253-01909717-y

27. Mukai K, Yamada K, Doi Y (1993) Kinetics and mechanism of heterogeneous hydrolysis of poly[(R)-3-hydroxybutyrate] film by PHA depolymerases. Int J Biol Macromol 15:361-366. https://doi.org/10.1016/0141-8130(93)90054-P

28. Biundo A, Ribitsch D, Guebitz GM (2018) Surface engineering of polyester-degrading enzymes to improve efficiency and tune specificity. Appl Microbiol Biotechnol 102:3551-3559. https://doi.org/10.1007/s00253-018-8850-7 
29. Timmins MR, Lenz RW, Clinton Fuller R (1997) Heterogeneous kinetics of the enzymatic degradation of poly( $\beta$-hydroxyalkanoates). Polymer (Guildf) 38:551-562. https://doi.org/10.1016/S0032-3861(96)00530-7

30. Barth M, Oeser T, Wei R, et al (2015) Effect of hydrolysis products on the enzymatic degradation of polyethylene terephthalate nanoparticles by a polyester hydrolase from Thermobifida fusca. Biochem Eng J 93:222-228. https://doi.org/10.1016/j.bej.2014.10.012

31. Mueller RJ (2006) Biological degradation of synthetic polyesters-Enzymes as potential catalysts for polyester recycling. Process Biochem.

https://doi.org/10.1016/j.procbio.2006.05.018

32. Zimmermann W, Billig S (2010) Enzymes for the Biofunctionalization of Poly(Ethylene Terephthalate). In: Advances in biochemical engineering/biotechnology. pp 97-120

33. Oda M, Yamagami Y, Inaba S, et al (2018) Enzymatic hydrolysis of PET: functional roles of three $\mathrm{Ca} 2+$ ions bound to a cutinase-like enzyme, Cut 190*, and its engineering for improved activity. Appl Microbiol Biotechnol 102:10067-10077. https://doi.org/10.1007/s00253-018-9374-X

34. Bradford MM (1976) A rapid and sensitive method for the quantitation of microgram quantities of protein utilizing the principle of protein-dye binding. Anal Biochem 72:248-254. https://doi.org/10.1016/0003-2697(76)90527-3

35. Al-Sabagh AM, Yehia FZ, Eissa AMMF, et al (2014) Glycolysis of poly(ethylene terephthalate) catalyzed by the Lewis base ionic liquid [Bmim][OAc]. Ind Eng Chem Res 53:18443-18451. https://doi.org/10.1021/ie503677w

36. Gan Q, Allen SJ, Taylor G (2003) Kinetic dynamics in heterogeneous enzymatic hydrolysis of cellulose: An overview, an experimental study and mathematical modelling. Process Biochem 38:1003-1018. https://doi.org/10.1016/S00329592(02)00220-0

37. Lonhienne T, Gerday C, Feller G (2000) Psychrophilic enzymes: Revisiting the thermodynamic parameters of activation may explain local flexibility. Biochim Biophys Acta - Protein Struct Mol Enzymol 1543:1-10. https://doi.org/10.1016/S0167-4838(00)00210-7

38. Gamerith C, Zartl B, Pellis A, et al (2017) Enzymatic recovery of polyester building blocks from polymer blends. Process Biochem 59:58-64. https://doi.org/10.1016/j.procbio.2017.01.004

39. Xu F, Ding H (2007) A new kinetic model for heterogeneous (or spatially confined) enzymatic catalysis: Contributions from the fractal and jamming (overcrowding) effects. Appl Catal A Gen 317:70-81. https://doi.org/10.1016/j.apcata.2006.10.014

40. Wei R, Oeser T, Then J, et al (2014) Functional characterization and structural modeling of synthetic polyester-degrading hydrolases from Thermomonospora curvata. AMB Express 4:1-10. https://doi.org/10.1186/s13568-014-0044-9

41. Fogler HS (2006) External diffusion effects on heterogeneous reactions. In: Elements of chemical reaction engineering, 4th ed. Pearson Education Inc.

42. Ingesson H, Zacchi G, Yang B, et al (2001) The effect of shaking regime on the rate and extent of enzymatic hydrolysis of cellulose. J Biotechnol 88:177-182. https://doi.org/10.1016/S0168-1656(01)00273-5 
43. Wei R, Oeser T, Schmidt J, et al (2016) Engineered bacterial polyester hydrolases efficiently degrade polyethylene terephthalate due to relieved product inhibition. Biotechnol Bioeng 113:1658-1665. https://doi.org/10.1002/bit.25941

44. Barth M, Wei R, Oeser T, et al (2015) Enzymatic hydrolysis of polyethylene terephthalate films in an ultrafiltration membrane reactor. J Memb Sci 494:182-187. https://doi.org/10.1016/j.memsci.2015.07.030

45. Maria G (2016) Quick identification of a simple enzyme deactivation model for an extended-Michaelis - Menten reaction type . Exemplification for the d -glucose oxidation with a complex enzyme deactivation kinetics. Comput Chem Eng 93:323330. https://doi.org/10.1016/j.compchemeng.2016.07.014

46. Nechwatal A, Blokesch A, Nicolai M, et al (2006) A contribution to the investigation of enzyme-catalysed hydrolysis of poly(ethylene terephthalate) oligomers. Macromol Mater Eng 291:1486-1494. https://doi.org/10.1002/mame.200600204

47. Khoonkari M, Haghighi AH, Sefidbakht Y, et al (2015) Chemical Recycling of PET Wastes with Different Catalysts. Int J Polym Sci 2015:. https://doi.org/10.1155/2015/124524

48. Herzog K, Müller RJ, Deckwer WD (2006) Mechanism and kinetics of the enzymatic hydrolysis of polyester nanoparticles by lipases. Polym Degrad Stab 91:2486-2498. https://doi.org/10.1016/j.polymdegradstab.2006.03.005

49. Kawai F, Oda M, Tamashiro T, et al (2014) A novel Ca2+-activated, thermostabilized polyesterase capable of hydrolyzing polyethylene terephthalate from Saccharomonospora viridis AHK190. Appl Microbiol Biotechnol 98:10053-10064. https://doi.org/10.1007/s00253-014-5860-y

50. Sulaiman S, You DJ, Kanaya E, et al (2014) Crystal structure and thermodynamic and kinetic stability of metagenome-derived LC-cutinase. Biochemistry 53:1858-1869. https://doi.org/10.1021/bi401561p

51. Wei R, Zimmermann W (2017) Microbial enzymes for the recycling of recalcitrant petroleum-based plastics: how far are we? Microb Biotechnol 10:1308-1322. https://doi.org/10.1111/1751-7915.12710

52. Castro AM de, Carniel A, Sirelli L, et al (2018) Enzyme-catalyzed simultaneous hydrolysis-glycolysis reactions reveals tunability on PET depolymerization products. Biochem Eng J 137:239-246. https://doi.org/10.1016/j.bej.2018.06.007

53. Kikkawa Y, Fujita M, Abe H, Doi Y (2004) Effect of water on the surface molecular mobility of poly(lactide) thin film: An atomic force microscopy study. Biomacromolecules 5:1187-1193. https://doi.org/10.1021/bm0345007

54. Kawai F, Kawabata T, Oda M (2020) Current State and Perspectives Related to the Polyethylene Terephthalate Hydrolases Available for Biorecycling. ACS Sustain Chem Eng 8:8894-8908. https://doi.org/10.1021/acssuschemeng.0c01638

55. Basu S, Brockman A, Gagare P, et al (2009) Chemical kinetics of Ru-catalyzed ammonia borane hydrolysis. J Power Sources 188:238-243. https://doi.org/10.1016/j.jpowsour.2008.11.085

56. Wolfenden R, Snider M, Ridgway C, Miller B (1999) The temperature dependence of enzyme rate enhancements [8]. J Am Chem Soc 121:7419-7420. https://doi.org/10.1021/ja991280p

57. Jencks WP (1997) From chemistry to biochemistry to catalysis to movement. Annu 
Rev Biochem 66:1-18. https://doi.org/10.1146/annurev.biochem.66.1.1

58. Wolfenden R (1969) Transition State Analogues for Enzyme Catalysis. Nature 223:704-705. https://doi.org/10.1038/223704a0

59. Carta D, Cao G, D’Angeli C (2003) Chemical Recycling of Poly(ethylene terephthalate) (PET) by Hydrolysis and Glycolysis. Environ Sci Pollut Res 10:390394. https://doi.org/10.1065/espr2001.12.104.8

60. Zhang L (2014) Kinetics of hydrolysis of poly(ethylene terephthalate) wastes catalyzed by dual functional phase transfer catalyst: A mechanism of chain-end scission. Eur J Pharmacol 742:1-5. https://doi.org/10.1016/j.eurpolymj.2014.08.007

61. Yoshioka T, Motoki T, Okuwaki A (2001) Kinetics of hydrolysis of poly(ethylene terephthalate) powder in sulfuric acid by a modified shrinking-core model. Ind Eng Chem Res 40:75-79. https://doi.org/10.1021/ie000592u

62. Mancini SD, Zanin M (2007) Post consumer pet depolymerization by acid hydrolysis. Polym - Plast Technol Eng 46:135-144. https://doi.org/10.1080/03602550601152945

63. Kao CY, Wan BZ, Cheng WH (1998) Kinetics of Hydrolytic Depolymerization of Melt Poly(ethylene terephthalate). Ind Eng Chem Res 37:1228-1234. https://doi.org/10.1021/ie970543q

64. Goje AS, Thakur SA, Diware VR, et al (2004) Chemical recycling, kinetics, and thermodynamics of hydrolysis of poly(ethylene terephthalate) waste with nonaqueous potassium hydroxide solution. Polym - Plast Technol Eng 43:369-388. https://doi.org/10.1081/PPT-120029969

65. Wolfenden R, Snider MJ (2001) The depth of chemical time and the power of enzymes as catalysts. Acc Chem Res 34:938-945. https://doi.org/10.1021/ar000058i

66. Åqvist J, Kazemi M, Isaksen GV, Brandsdal BO (2017) Entropy and Enzyme Catalysis. Acc Chem Res 50:199-207. https://doi.org/10.1021/acs.accounts.6b00321 


\section{Caption for figures}

Figure 1: Time course of enzymatic hydrolysis of post-consumer poly(ethylene terephthalate) (PC-PET) for different substrate concentrations. Reactions were carried out at $70{ }^{\circ} \mathrm{C}$ with PCPET particle size range of 0.075-0.250 mm, $200 \mathrm{mmol} \mathrm{L}^{-1}$ sodium phosphate buffer ( $\mathrm{pH} 7.0$ ), and $1.0 \mathrm{mg}_{\text {protein }} \mathrm{mL}^{-1}$ of Humicola insolens cutinase (For interpretation of the references to color in this figure legend, the reader is referred to the web version of this article).

Figure 2: Initial post-consumer poly(ethylene terephthalate) (PC-PET) hydrolysis rate for different reactor stirring speeds: 100 (closed square), 400 (open circle), and $800 \mathrm{rpm}$ (closed triangle). Reactions were carried out at $70{ }^{\circ} \mathrm{C}$, using PC-PET with the particle size range of

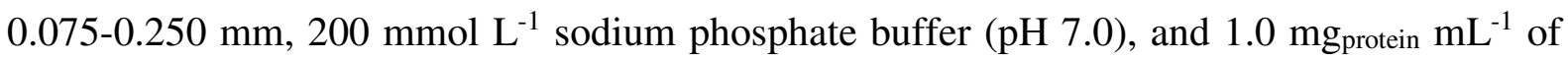
biocatalyst.

Figure 3: Molar concentration of products obtained from post-consumer poly(ethylene terephthalate) (PC-PET) hydrolysis in different initial concentrations of terephthalic acid (TPA), mono(2-hydroxyethyl) terephthalate (MHET), and bis(2-hydroxyethyl) terephthalate (BHET). Reactions were carried out at $70{ }^{\circ} \mathrm{C}$, in sodium phosphate buffer $200 \mathrm{mmol} \mathrm{L}{ }^{-1}(\mathrm{pH}$ 7.0), $1.0 \mathrm{mg}_{\text {protein }} \mathrm{mL}^{-1}$ of $\mathrm{HiC}, 50 \mathrm{~g} \mathrm{~L}^{-1}$ of PC-PET with a particle size range of $0.250-0.600$ $\mathrm{mm}$, under $800 \mathrm{rpm}$ stirring speed, the effect of the addition of TPA and MHET was evaluated after $96 \mathrm{~h}$, and for BHET, it was analyzed after $24 \mathrm{~h}$.

Figure 4: Adjustment of the heterogeneous kinetic model for post-consumer poly(ethylene terephthalate) (PC-PET) hydrolysis by Humicola insolens cutinase (HiC) using different substrate concentrations and two PC-PET granulometric size ranges: 0.075-0.250 mm (F1, squares) and 0.250-0.600 (F2, triangles). Reactions were carried out at $70{ }^{\circ} \mathrm{C}, 200 \mathrm{mmol} \mathrm{L}^{-1}$ sodium phosphate buffer ( $\mathrm{pH} 7.0$ ), $1.0 \mathrm{mg}_{\text {protein }} \mathrm{mL}^{-1}$ of $\mathrm{HiC}$, under $800 \mathrm{rpm}$ stirring speed.

Figure 5: Effect of temperature and substrate concentration on the initial rate of for postconsumer poly(ethylene terephthalate) (PC-PET) hydrolysis and adjustment of the kinetic 
model (solid line). Reactions were carried out under $800 \mathrm{rpm}$ stirring speed, $200 \mathrm{mmol} \mathrm{\textrm {L } ^ { - 1 }}$ sodium phosphate buffer ( $\mathrm{pH} 7.0$ ), $1.0 \mathrm{mg}_{\text {protein }} \mathrm{mL}^{-1}$ of Humicola insolens cutinase (HiC), and PC-PET with the particle size range of $0.075-0.250 \mathrm{~mm}$. (For interpretation of the references to color in this figure legend, the reader is referred to the web version of this article).

Figure 6: Arrhenius plot for post-consumer poly(ethylene terephthalate) (PC-PET) hydrolysis using Humicola insolens cutinase (HiC). The kinetic parameters were estimated based on enzyme-limiting conditions. 


\section{Caption for tables}

Table 1: The estimated parameter for the kinetic model for post-consumer poly(ethylene terephthalate) (PC-PET) hydrolysis by Humicola insolens cutinase (HiC) for two substrate granulometric size ranges: $0.075-0.250 \mathrm{~mm}$ (F1, squares) and 0.250-0.600 (F2, triangles). Reactions were carried out at $70{ }^{\circ} \mathrm{C}, 200 \mathrm{mmol} \mathrm{L}^{-1}$ sodium phosphate buffer ( $\left.\mathrm{pH} 7.0\right), 1.0$ $\mathrm{mg}_{\text {protein }} \mathrm{mL}^{-1}$ of $\mathrm{HiC}$, under $800 \mathrm{rpm}$ stirring speed.

Table 2: Kinetic parameters of enzymatic post-consumer poly(ethylene terephthalate) (PCPET) hydrolysis model for different temperatures. The reactions were performed under 800 rpm stirring speed, phosphate buffer $200 \mathrm{mmol} \mathrm{L}^{-1}$ (pH 7.0), Humicola insolens cutinase (HiC) concentration of $1.0 \mathrm{mg}_{\text {protein }} \mathrm{mL}^{-1}$, and PC-PET with a particle size range $0.075-0.250 \mathrm{~mm}$.

Table 3: Activation parameters of enzymatic post-consumer poly(ethylene terephthalate) (PCPET) hydrolysis model. The kinetic parameters used on Arrhenius and Eyring-Polanyi equations were estimated based on enzyme-limiting conditions. 


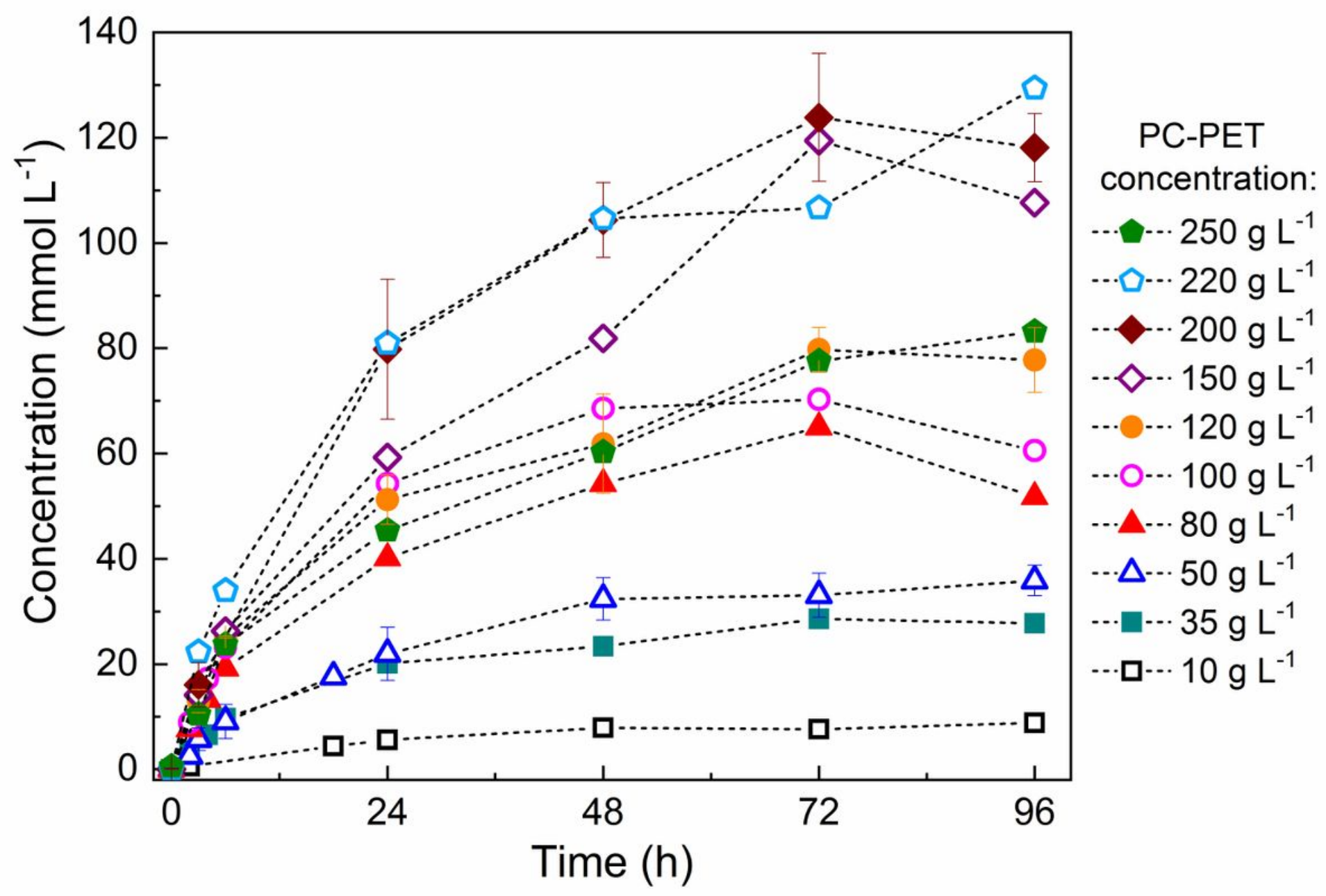

Figure 1

Time course of enzymatic hydrolysis of post-consumer poly(ethylene terephthalate) (PC-PET) for different substrate concentrations. Reactions were carried out at $70 \mathrm{oC}$ with PC-PET particle size range of 0.075-0.250 mm, $200 \mathrm{mmol} \mathrm{L-1} \mathrm{sodium} \mathrm{phosphate} \mathrm{buffer} \mathrm{(pH} \mathrm{7.0),} \mathrm{and} 1.0$ mgprotein mL-1 of Humicola insolens cutinase (For interpretation of the references to color in this figure legend, the reader is referred to the web version of this article). 


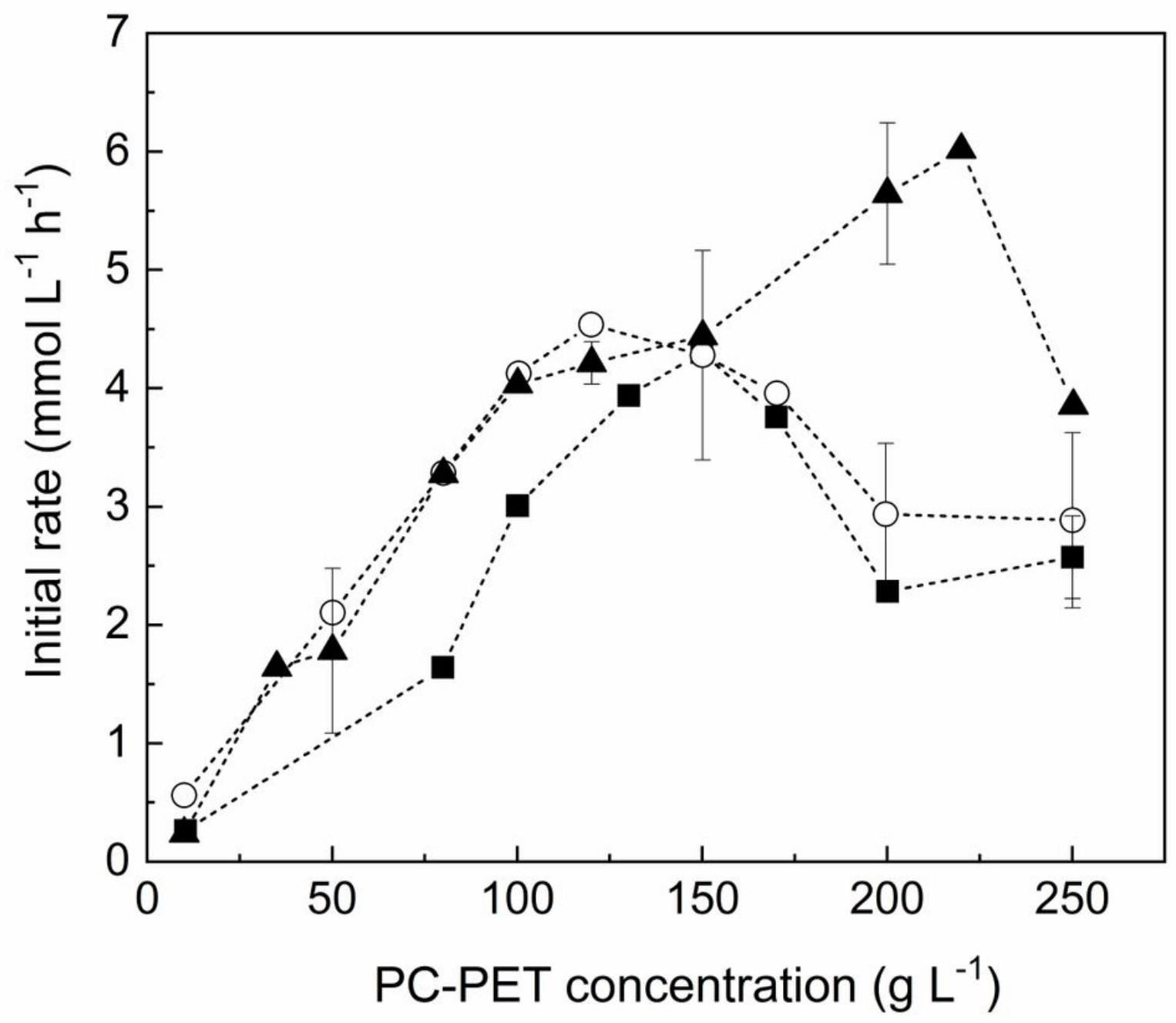

Figure 2

Initial post-consumer poly(ethylene terephthalate) (PC-PET) hydrolysis rate for different reactor stirring speeds: 100 (closed square), 400 (open circle), and $800 \mathrm{rpm}$ (closed triangle). Reactions were carried out at $70 \mathrm{oC}$, using PC-PET with the particle size range of $0.075-0.250 \mathrm{~mm}, 200 \mathrm{mmol} \mathrm{L}-1$ sodium phosphate buffer ( $\mathrm{pH} 7.0)$, and 1.0 mgprotein $\mathrm{mL}-1$ of biocatalyst. 


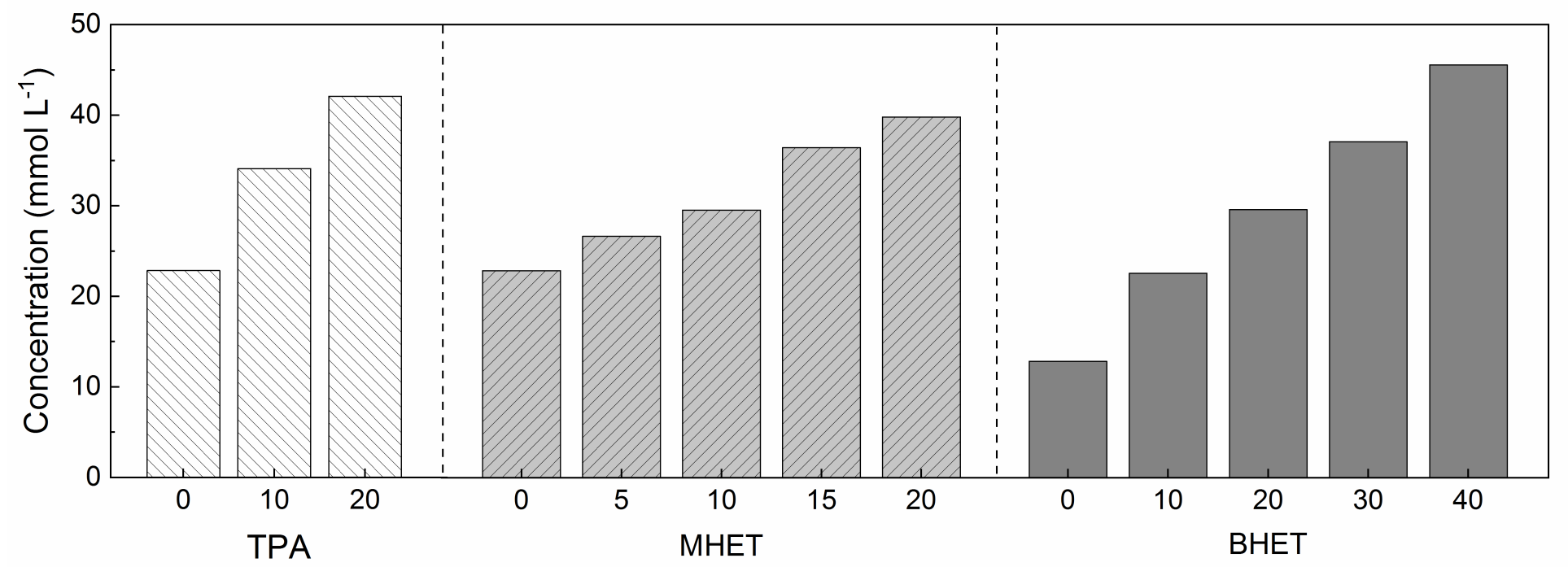

Figure 3

Molar concentration of products obtained from post-consumer poly(ethylene terephthalate) (PC-PET) hydrolysis in different initial concentrations of terephthalic acid (TPA), mono(2-hydroxyethyl) terephthalate (MHET), and bis(2-hydroxyethyl) terephthalate (BHET). Reactions were carried out at 70 oC, in sodium phosphate buffer $200 \mathrm{mmol} \mathrm{L-1}$ (pH 7.0), 1.0 mgprotein mL-1 of HiC, $50 \mathrm{~g} \mathrm{L-1}$ of PC-PET with a particle size range of $0.250-0.600 \mathrm{~mm}$, under $800 \mathrm{rpm}$ stirring speed, the effect of the addition of TPA and MHET was evaluated after $96 \mathrm{~h}$, and for BHET, it was analyzed after $24 \mathrm{~h}$. 


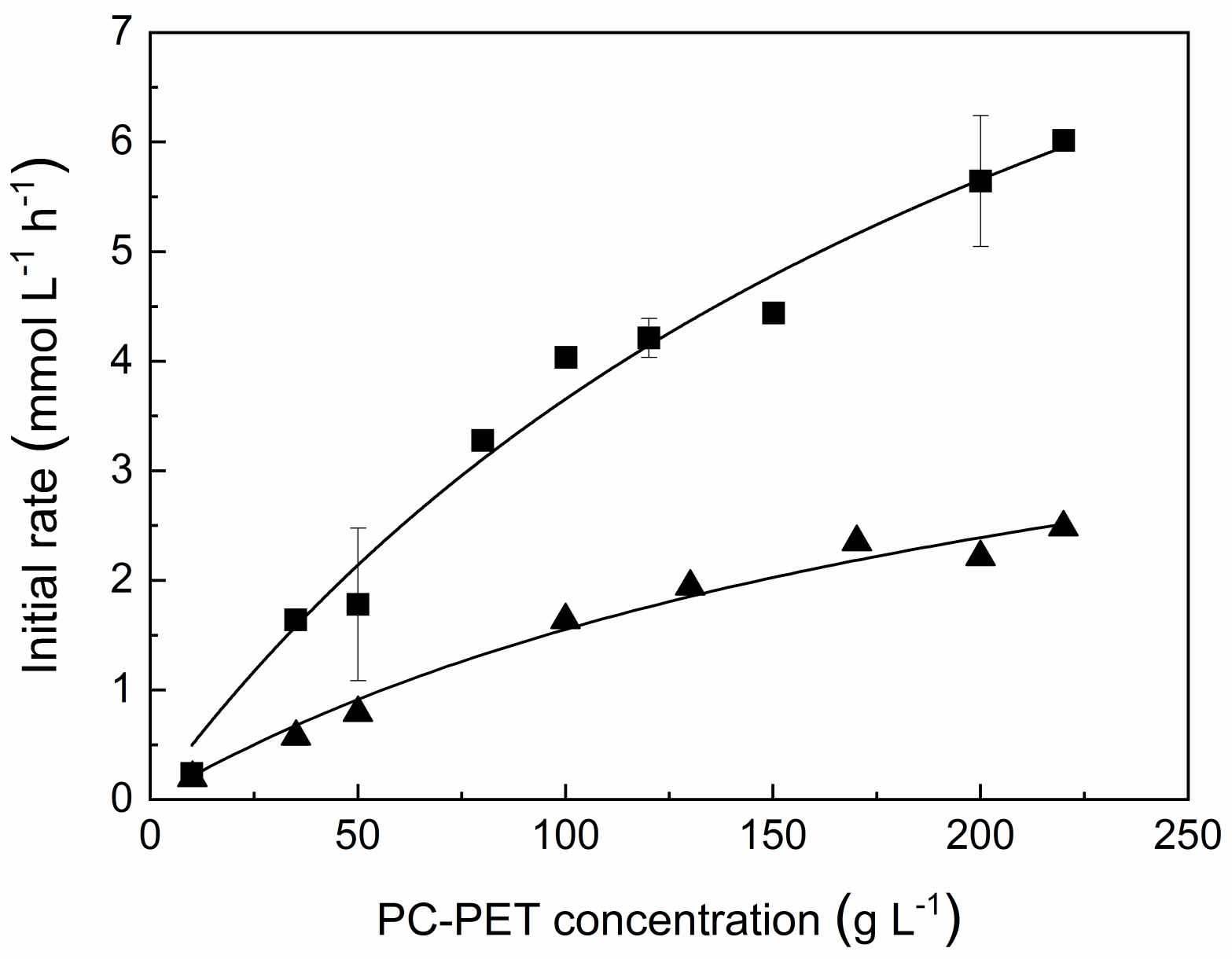

Figure 4

Adjustment of the heterogeneous kinetic model for post-consumer poly(ethylene terephthalate) (PC-PET) hydrolysis by Humicola insolens cutinase $(\mathrm{HiC})$ using different substrate concentrations and two PC-PET granulometric size ranges: $0.075-0.250 \mathrm{~mm}$ ( $\mathrm{F} 1$, squares) and $0.250-0.600$ (F2, triangles). Reactions were carried out at $70 \mathrm{oC}, 200 \mathrm{mmol} \mathrm{L}-1$ sodium phosphate buffer (pH 7.0), 1.0 mgprotein mL-1 of HiC, under 800 rpm stirring speed. 


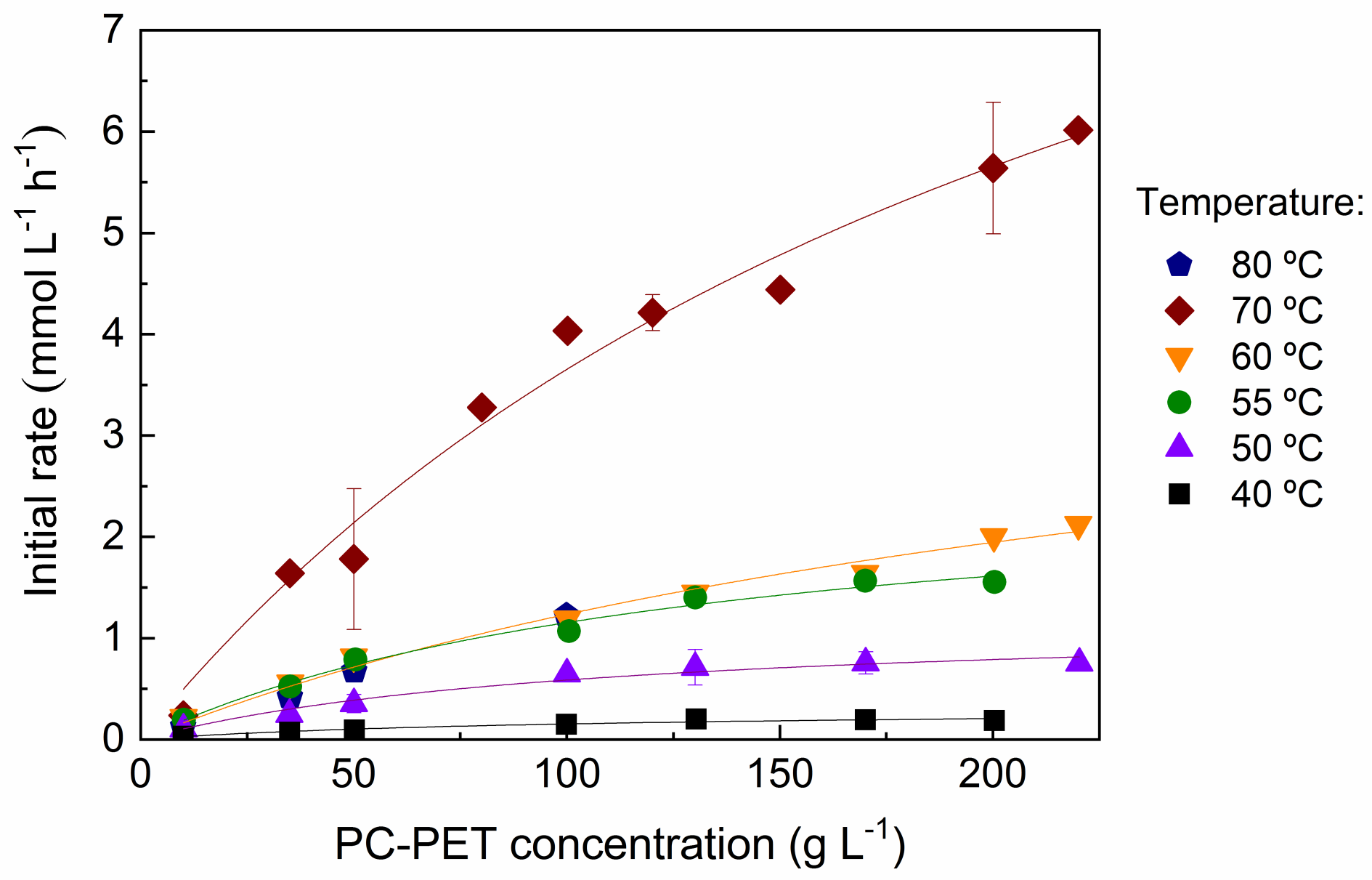

Figure 5

Effect of temperature and substrate concentration on the initial rate of for post-consumer poly(ethylene terephthalate) (PC-PET) hydrolysis and adjustment of the kinetic model (solid line). Reactions were carried out under $800 \mathrm{rpm}$ stirring speed, $200 \mathrm{mmol} \mathrm{L-1}$ sodium phosphate buffer ( $\mathrm{pH} 7.0$ ), 1.0 mgprotein $\mathrm{mL}-1$ of Humicola insolens cutinase $(\mathrm{HiC})$, and PC-PET with the particle size range of $0.075-0.250 \mathrm{~mm}$. (For interpretation of the references to color in this figure legend, the reader is referred to the web version of this article). 


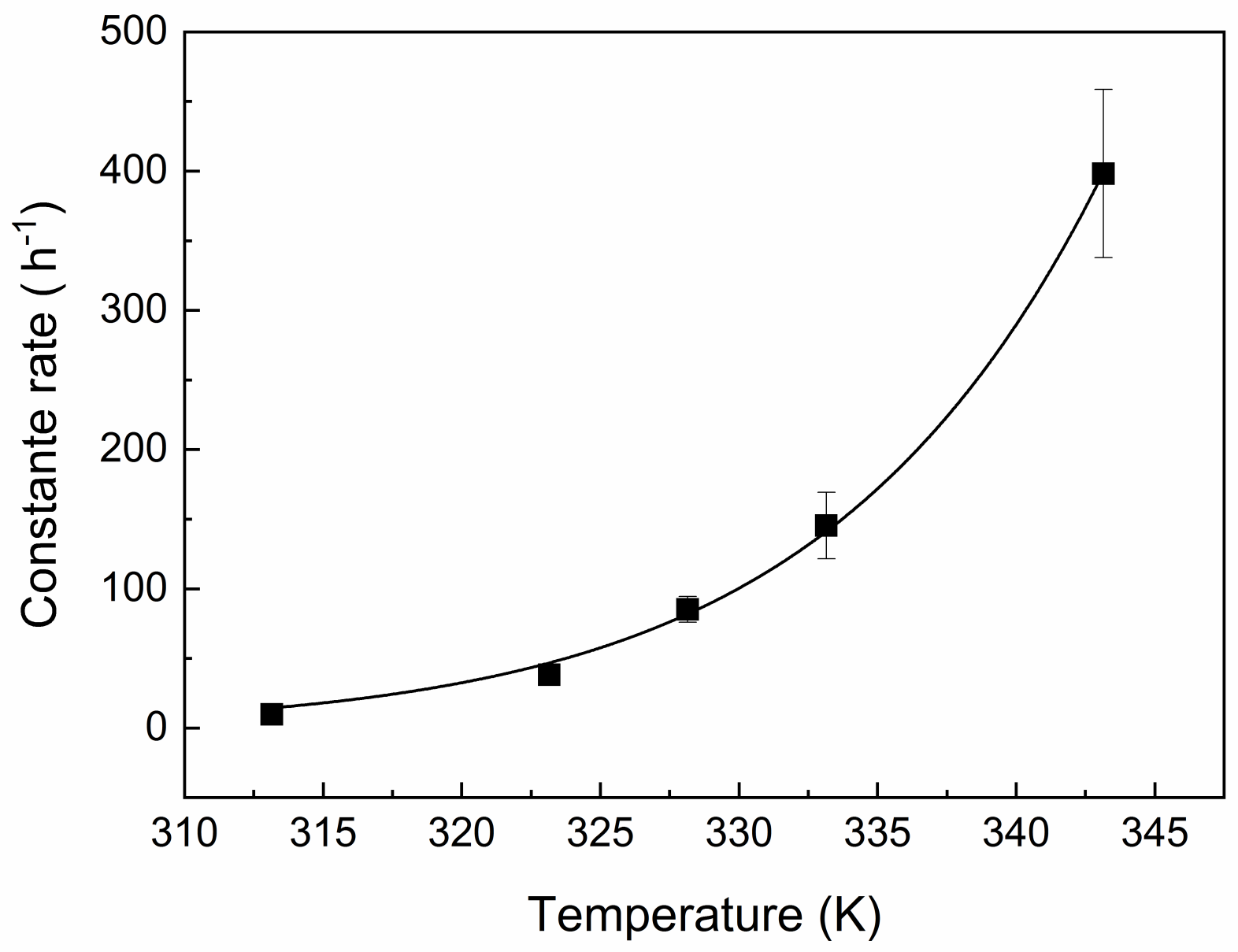

Figure 6

Arrhenius plot for post-consumer poly(ethylene terephthalate) (PC-PET) hydrolysis using Humicola insolens cutinase $(\mathrm{HiC})$. The kinetic parameters were estimated based on enzyme-limiting conditions. 